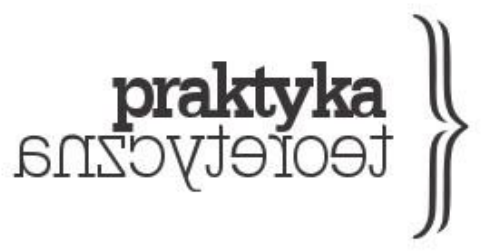

Praktyka Teoretyczna

Numer 2(32)/2019

ISSN 2081-8130

DOI: $10.14746 /$ prt.2019.2.0 www.praktykateoretyczna.pl

\title{
SŁABY OPÓR. OBRAZ, WSPÓLNOTA I UTOPIA POZA PARADYGMATEM HEROICZNYM
}

\author{
EWA MAJEWSKA
}

\begin{abstract}
Abstrakt: Niniejszy artykuł stanowi wprowadzenie do numeru Praktyki Teoretycznej poświęconego problematyce słabego oporu. Oprócz głównych inspiracji teoretycznych zjawiska, które można by pokrótce nazwać zwrotem w stronę codzienności czy też odwrotem od heroicznego modelu podmiotowości, redaktorka omawia też opublikowane w numerze artykuły.
\end{abstract}

Słowa kluczowe: słaby opór, kontrpubliczności, słaby mesjanizm, podmiot, wspólnota. 


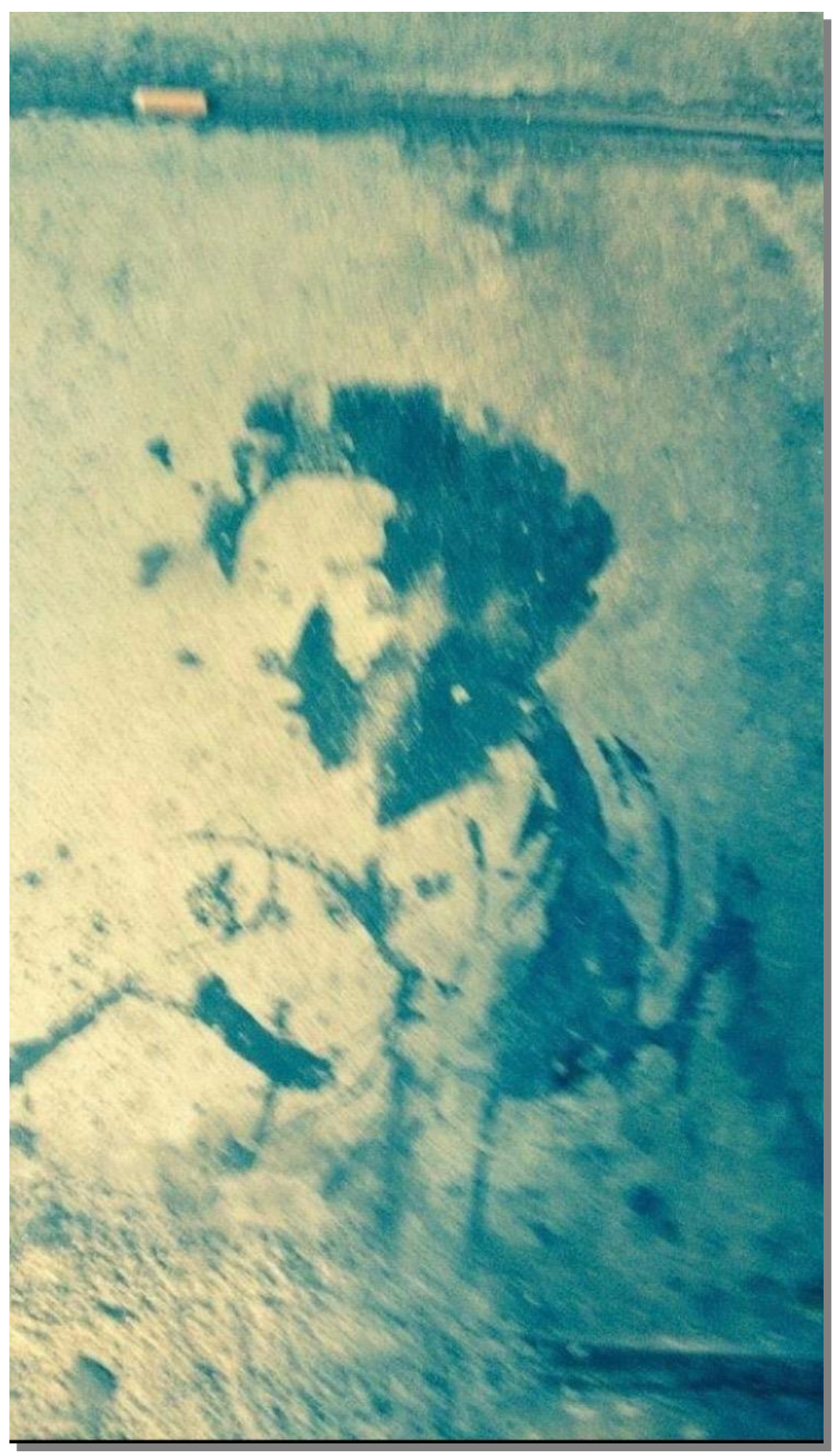

Ewa Majewska, Staba róża, Ateny 2015. 
Kiedy więc nagle pojawia się wielość, wydaje się, że to cud. Kiedy wielość powstaje w konstytutywnym procesie stawania się jakimś „my”, mogą się zdarzyć straszne i wspaniałe rzeczy. Wspaniałe jest na przykład to, że w takich chwilach można na nowo tworzyć rzeczy najwiażniejsze: troskę, godność, kolektywne zmiany naszego życia, co miało ostatnio miejsce na placach i w parkach Madrytu, Kairu, Nowego Jorku, Aten i Stambułu. Sibylle Peters $(2014,69)$

Niniejszy numer Praktyki Teoretycznej posiada szereg inspiracji teoretycznych, które chciałabym pokrótce omówić. Następnie opiszę kilkanaście przykładów pojawiania się kategorii słabości w tekstach i wydarzeniach w Polsce, a później przejdę do zapowiedzi zebranych w numerze artykułów.

W ostatnich zdaniach rozdziału o panu i niewolniku w Fenomenologii Ducha Hegel diagnozuje upór jako wolność pozostająca jeszcze w warunkach zniewolenia (Hegel 1963, 228). Ta perspektywa otwiera możliwość budowania krytycznej, emancypacyjnej teorii według nietypowego, nieheroicznego i pozbawionego absolutystycznych tendencji scenariusza. Jako jego bezpośrednie rozwinięcie można traktować choćby Manifest Komunistyczny Marksa I Engelsa, którego zakończenie określa proletariat jako klasę niemająca już nic do stracenia oprócz kajdan. Fragment Hegla o uporze jest też zapowiedzią walki dokonywanej w rzekomym zaciszu domowej harówy, oporu osób doświadczających przemocy i poniżenia, wyzyskiwanych migrantek bez praw i przywilejów, redukowanych w słynnym Agambenowskim projekcie Homo Sacer do biernych ofiar absolutnej suwerenności (zob. Agamben 1998), ale posiadających i wyrażających przecież swoją sprawczość (zob. Butler I Spivak 2007; Butler 2010; hooks 2013 i inne). W napisanej wspólnie książce Who Sings the Nation State Judith Butler i Gayatri Spivak domagają się uznania sprawczości opresjonowanych, co w przypadku Butler jest bezpośrednim rozwinięciem jej badań nad mową nienawiści i cenzura, w których pokazała ona, że nie każdy akt nienawiści jest sukcesem, a wiele z nich prowadzi do oporu po stronie atakowanych i ostatecznie do porażki agresora (Butler 2010). Dla tej badaczki jest więc oczywiste, że najbardziej nawet opresyjna biopolityczna władza suwerenna, choćby wyposażona była we wszelkie narzędzia kontroli i destrukcji, nie posiada nigdy absolutnej władzy, a z pewnościa - nie pozbawia całej sprawczości tych, których sobie podporządkowuje. 
Oczywiście tematyka subordynacji prowadzi również do myślenia o konformizmie. Czyż gigantyczny tryumf kapitalizmu po rozpadzie tzw. Bloku Wschodniego w 1989 roku, sukces neoliberalnej produktywności i skuteczna prekaryzacja pracownic i pracowników nie stanowi dla szeregu intelektualistów zachęty, a nawet zobowiązania do rezygnacji z wszelkich form oporu? Zapewne wiele osób $\mathrm{z}$ radością wita ten defetystyczny moment domniemanej porażki radykalizmu i oporu, serdecznie dziękując historii i światu za dostarczenie poręcznej wymówki na wypadek zarzutów o konformizm, oportunizm czy podporządkowanie. Niniejszy numer Praktyki Teoretycznej stanowi zachętę do przemyślenia innej optyki, takiej, w której zobowiązanie do stawiania oporu nie jest traktowane wyłącznie jako historyczna konieczność przydarzająca się wszystkim innym hegemonicznego, męskiego podmiotu, ale przede wszystkim jako obowiązek szukania takich teorii i praktyk oporu, które w dzisiejszym świecie moga przynieść choćby odrobinę wolności. W czasach, gdy wydaje się, że „nie ma alternatyw”, a coś takiego jak społeczeństwo przestało istnieć, pojawia się co doskonale pokazuja zebrane tu teksty - cały szereg alternatyw dla głównego nurtu i dominującego porządku. Nie ma powodu, by ignorować te perspektywy, wydaje się też wskazanym, byśmy uczyły się i uczyli definiować na nowo, co dziś jest rewolucją lub reformizmem, porządkiem czy zakłóceniem, co sugerują choćby Antonio Negri i Michael Hardt w książce Assembly (zob. 2017).

Zebrane w niniejszym numerze Praktyki Teoretycznej teksty na rozmaite sposoby podważają hegemonię tradycyjnej, wciąż jeszcze dość popularnej alternatywy, dzielącej sprawczość na dwa formaty: heroiczny i bierny/wymazany (zob. Steyerl 2012, Ahmed 2013, Butler 2013, Honig 2013, Jaworska 2019). Podobnie jak Bonnie Honig, która podważa tradycyjne odczytania Antygony, a tragedię Sofoklesa prezentuje jako opowieść o antypatriarchalnym, siostrzanym sojuszu Ismeny i Antygony (Honig 2013), również autorki zebranych tu tekstów pokazuja nie tylko możliwość słabej sprawczości, ale też jej nieoczekiwane implikacje i sojusze, jakie pozwala ona budować.

Samo pojęcie oporu i broni słabych pojawia się w dwóch książkach, które miały szczególne znaczenie dla wykrystalizowania się problematyki niniejszego numeru Praktyki Teoretycznej. Jest to słynny esej Vaclava Havla Siła bezsilnych z 1978 roku oraz książka Jamesa Scotta Weapons of the Weak z roku 1985. Pierwsza z wymienionych publikacji miała szczególne znaczenie dla kształtowania się pierwszej „Solidarności” w 1978 roku - esej Havla przełożono na język polski i kolportowano w naszym kraju już w 1979 roku, a działacze opozycyjni, jak choćby Zbigniew Bujak, otwarcie mówią o swojej fascynacji tym utworem I zarysowaną w nim perspektywa. Dla autorki niniejszego wstępu, podobnie, jak dla większości osób związanych z Praktykeq Teoretyczna, „Solidarność” pozostaje wydarzeniem pod wieloma względami problematycznym, zaś polityczny liberalizm, a następnie neoliberalizm tak jej działaczek i działaczy, jak i autora Siły bezsilnych raczej prowokuje 
do krytyki, niż budzi entuzjazm. Niemniej, esej Havla wskazuje na szereg problemów I strategii teoretycznych oraz politycznych, które w czasach krytycznego demontażu męskiego, mocnego i heroicznego podmiotu niewatpliwie warto przypomnieć. Dla Havla ustalony porządek mocarstw światowych sprawiających wrażenie niepokonanych nie stanowi przeszkody do stawiania oporu. Jego zdaniem kontestacja musi jednak przyjąć inne, bardziej zwyczajne i mniej heroiczne formy. Sklepikarz - figura „zwykłego człowieka”, którą Havel przeciwstawia uzbrojonym imperiom - to postać wolna od marzeń o wielkich zwycięstwach, co bynajmniej nie czyni go konformistą. Proste czynności, jakie wykonuje, by wyrazić swój opór, są dostępne dla każdego i każdej (Havel 2011). Podobnie dzieje się w przypadku chłopów z krajów Azji południowo-wschodniej, których sytuacji poświęcił swoją analizę Scott. Ich protesty to na ogół przemarsze, czasem połączone z artykulacja postulatów, ale czasem polegające po prostu na uporze i niezgodzie na zawłaszczanie ziemi, niegodziwe warunki pracy czy inne nadużycia lokalnych i globalnych możnowładców (Scott 1985). Te odległe geograficznie doświadczenia łączy poczucie słabości i gotowość do eksplorowania właściwych jej strategii oporu poza paradygmatem heroicznym.

Choć napisane przez mężczyzn i niewyrażające feministycznej wrażliwości na problematykę płci, obie te książki są dla współczesnego feminizmu ważnymi punktami odniesienia, ponieważ to właśnie feministyczna filozofia polityczna i studia kulturowe stawiaja pod znakiem zapytania męskoosobowy, heroiczny i oderwany od kontekstu, kolonialny podmiot Zachodu (Spivak 2011, Lorey 2015, Federici 2004 i in.). Perspektywa współczesnego feminizmu, która dowartościowuje pracę afektywną i reprodukcyjną oraz krytykuje indywidualizm i heroizm właściwy dla klasycznej, liberalnej podmiotowości, wymaga uznania za pełnowartościowe owych niespektakularnych strategii i taktyk, jak też podmiotowości, które te generują. Na gruncie teorii feministycznej dokonuje tego między innymi Isabel Lorey, która w eseju State of Insecurity nie tylko poddaje krytyce neoliberalne formy zarządzania I kontroli, ale też przemocowy, kolonialny i patriarchalny konstrukt hegemonicznej podmiotowości Zachodu. Z perspektywy niniejszego numeru szczególnie cenne wydają się jej obserwacje dotyczące historii prekarności, zjawiska w jej ujęciu bynajmniej nie nowego, ale niezauważanego w klasycznych teoriach podmiotu, zakładajacych przecież istnienie wszystkich tych niewidzialnych i zapracowanych jednostek utrzymujących Podmiot Zachodu przy życiu i władzy (Lorey 2015).

Zebrane tu teksty niewatpliwie różnią się swoimi przesłankami, metodologią i punktami dojścia, ale w każdym z nich do głosu dochodzi nie tyle płaskie odrzucenie „logiki całości”, co raczej wielowymiarowe, miejscami dialektyczne eksplorowanie możliwości utopii, heterotopii dystopii - tak w odniesieniu do własnej pozycji teoretycznej, jak i do współczesnej teorii i kultury. Perspektywa słabości ze swoim odrzuceniem heroizmu, kulturowej białej, hegemonicznej męskości i ze swoją tendencją do zamieszkiwania peryferii 
i marginesu, a nie centrum, wybrzmiewa jako zapowiedź emancypacji, a nie jej porażki. Zanim przejdę do omówienia artykułów zawartych w numerze, chciałabym zwrócić uwagę na jedną znacząca kwestię metodologiczną dotycząca feministycznej teorii i jej recepcji w ostatnich latach (na ogół przyjmującej postać marginalizacji) w teoretycznym mainstreamie. Myślę, że podobnie jak feministyczna polityka, tak i feministyczna teoria nadal traktowana jest zazwyczaj jak swego rodzaju margines aktywizmu oraz badań nad kulturą i społeczeństwem. Wielu teoretyków nadal nie ma za sobą lektury ani jednej książki feministycznej czy z obszaru teorii queer. Ten numer Praktyki Teoretycznej świadomie nie został skonstruowany jako po prostu feministyczny. Zawiera on jednak oczywiście teksty feministyczne oraz takie, w których feminizm czy teoria queer zostaja tylko wspomniane. Mam nadzieję, że taka strategia nie zostanie potraktowana jako kolejna odsłona marginalizacji feminizmu, ale raczej jako wyraz świadomości i element praktyki, w której perspektywa feministyczna jest jedną z kluczowych dla współczesnej filozofii, teorii kultury i nauk społecznych. Taka świadoma ucieczka od (auto)marginalizacji jest podyktowana kwestiami strategicznymi, ale też rozpoznaniem centralnej pozycji dyskursu feministycznego we współczesnej kulturze, naukach społecznych i humanistyce.

Tendencja wyniosłego marginalizowania feminizmu zaczyna powoli ustępować, a tym samym takie autorki jak Judith Butler czy Silvia Federici znajduja dla siebie miejsce również w naukowym mainstreamie - choć wciąż z trudem. Niemniej chciałabym wyraźnie i z pewnym niepokojem podkreślić, że nadal większość analiz prekarności czy nowoczesności, nie wspominając o wielu innych tematach, pomija perspektywę feministyczną. Podobnie analizy współczesnej polityki antyfaszystowskiej niezwykle często ignorują znaczenie masowych demonstracji feministycznych z ostatnich lat, wciąż postrzegając je jako margines polityki. A przecież protesty kobiece są par excellence polityką antyfaszystowską, zwróconą przeciw współczesnym formom politycznej tyranii, być może najbardziej rozpowszechnioną w dzisiejszych społeczeństwach. W szeregu artykułów polskie i zagraniczne autorki pokazują tę centralną pozycję feminizmu zarówno we współczesnych walkach z faszyzmem, jak i na innych polach (zob. Majewska, Korolczuk, Kubisa i Rakowska 2019, Majewska 2018 $\mathrm{i}$ in.). Wydaje mi się, że ignorowanie wskazanej tu tendencji przynosi ogromne straty nie tyle dla feministycznej teorii i praktyki, które akurat w ostatnich latach przeżywają wyraźny rozwój, co raczej dla polityki, nauk społecznych i humanistyki, które najpewniej dopiero w przyszłości odkryja, co właściwie pomijały.

Wśród wydawnictw zagranicznych z perspektywy tematyki niniejszego numeru kluczowa pozycją jest oczywiście książka Willful Subject Sary Ahmed (2014). Autorka już na początku przypomina świetnie znaną z baśni braci Grimm i innych autorów figurę „krnąbrnego dziecka”, które nie słucha poleceń osób starszych, nie szanuje autorytetów, ale przede wszystkim - jest uparte i działa według własnej woli, często podejmując ogromne 
ryzyko i narażając się na niebezpieczeństwo. Figura małego uparciucha jest przez Ahmed traktowana jako wypadkowa społecznej i kulturowej presji oraz projekt dążącej do rozwoju i wiedzy (młodej) podmiotowości. Od krnąbrnego dziecka, które zdaje się nikogo nie słuchać, Ahmed płynnie przechodzi do podmiotowości queerowej, ale nie takiej, która światu rzuca heroiczne wyzwanie, tylko takiej, która w małych gestach dziecięcego oporu znajduje swoją trajektorię rozwoju lub porażki. Problem woli, centralny dla całej książki, ostatecznie również narzucający bardzo szeroki, filozoficzny horyzont podjętych przez Ahmed rozważań, okazuje się nie tyle zbudowany ze spiżu, trwały, spójny, i pewny, co będący raczej serią błędów i omyłek. Wiąże się on też z odmową gotowości (willfulness) do słuchania rozkazów i podporządkowania. Jak pisze Ahmed na początku książki, „»wola« jest nazwą nadawana w historii albo przez nią samej możliwości odstępstwa/dewiacji” (2014, 11).

Zarysowana przez Ahmed pozycja uparciucha stanowi w moim przekonaniu doskonałe uzupełnienie antyneoliberalnej narracji o porażce jako queerowej sztuce oporu, zaproponowanej przez Jacka Halberstama w The Queer Art of Failure (2011). Odpowiedzia na neoliberalne ideały produktywności i wydajności są w przekonaniu autora/ki rozmaite porażki sztywnej polityki tożsamościowej, zaburzenia w matrycy ideologicznej reprodukcji potęgujące nieuchronną katastrofę nie tylko hegemonicznej męskości, ale również globalnego systemu wyzysku. Używając zapoczątkowanej przez Stuarta Halla „niskiej teorii”, Halberstam dostosowuje również własną metodę pracy do omawianej nieudolności i porażki, kontestując w ten sposób jedną z ważniejszych, a na pewno bardziej męczących, form uporczywej hegemonii męskiej tożsamości heroicznej. Wybierając niską teorię, dzieła popkultury i kultury niepopularnej, więc też marginalnej, sztuki awangardowej, Halberstam rezygnuje z wzniosłości na rzecz brzydoty, nieuchronnie zbliżając się do tego, co Diderot w Paradoksie o aktorze sportretował jako niewygodną, dialektyczną prawdę sztuki: mianowicie, że do największych artystycznych i etycznych uniesień prowadzą widzów i widzki działania kreatur często bynajmniej ani moralnych, ani wzniosłych, ludzi raczej podłego sortu (Diderot 1958; Ochocki 2007).

Swego rodzaju szorstkość dialektyki, charakterystyczna dla niej, choć przez wielu odrzucana tendencja do, jak nazwał to Benjamin, przechodzenia przez sprawy zwykłe i trywialne, jest też wątkiem obecnym u innego autora, mianowicie u Gianniego Vattimo, którego projekt „myśli słabej” (pensiero debole) miał być zwrotem w kierunku dialektyki (Vattimo 1992; Zawadzki 2003). W eseju Dialektyka, różnica, słaba myśl Vattimo wyjaśnia swoje nagłe zainteresowanie dialektyką jako próbę wyakcentowania w niej zmiany, różnicy i doświadczenia. Tekst ten dość szczegółowo omawia w naszym numerze Katarzyna Szafranowska, niemniej warto zasygnalizować, że choć w Polsce faktycznie jest to chyba najczęściej cytowany artykuł filozoficzny dotyczący słabości, tu zajmuje on miejsce jednego z wielu punktów odniesienia dla rozwijanej tutaj perspektywy teoretycznej i praktycznej. 
W interpretacji Andrzeja Zawadzkiego słaba myśl przypomina Foucaultowską „heterotopię" - nie jest próbą realizacji nowego, ale raczej pracą na tym, co zastane, nad przekształcaniem języka, fundowaniem jego nawet niespodziewanych form w ramach świata, który istnieje, a nie „pozaświatowo” (Zawadzki 2003, 175; Foucault 1984). Choć Foucault nie pisał tego wprost, to heterotopia pozostaje w jego rozumienia jakimś osłabieniem utopii, podług scenariusza innego ważnego dla niniejszego numeru autora, Borisa Groysa. Publikowany przez nas w polskim przekładzie esej Słaba awangarda podnosi kwestię umyślnego osłabiania dzieła artystycznego w awangardowym wysiłku budowania „mesjańskiej wspólnoty”, która ma nadejść, bez mistycznych czy religijnych odniesień. Zdaniem Groysa słaba awangarda znajduje uniwersalne środki jednocześnie budujące i komunikujące wspólnotę. I to czyni ją szczególnie bliską heterotopii. Joseph Beuys zapraszający publiczność do zrozumiałych i powszechnie znanych działań jak dyskusja czy głosowanie; Kazimierz Malewicz rozsadzający figurację prostymi figurami geometrycznymi; działania współczesnych awangard również budują wspólnotę doświadczenia, osłabiająca zarówno wydumaną, heroiczną i stereotypowo męską pozycję geniusza, jak i kulturowe dystynkcje.

Wbrew deklarowanemu niemal na każdej stronie Strukturalnych prz̨ekształcen sfery publiçnej Habermasa przywiązaniu autora do powszechności, demokracji i partycypacji, jego wizja sfery publicznej powtarza wszystkie klasyczne wykluczenia i hierarchie typowe dla arystotelejskiej i późniejszej konserwatywnej polityki (2008). Jest to przedmiot szeregu krytyk wystosowanych wobec tego autora, zwłaszcza zaś tej dokonanej przez Aleksandra Klugego i Oskara Negta w ich książce poświęconej proletariackim sferom publicznym (2016; Marzec 2015, Foucault 1984). Również Nancy Fraser, pisząc o feministycznych sferach publicznych, zwraca uwagę na to, jak hegemoniczny, męski, biały i zamożny model publiczności nie tylko wyklucza, ale też prowadzi do opresji kobiet $\mathrm{i}$ innych marginalizowanych grup (1992; 2014). Z tej perspektywy właśnie - kontrpubliczności wykluczanych innych - pisałam w książce Kontrpubliczności ludowe i feministyczne. Wczesna „Solidarnośc” i Czarne Protesty (zob. Majewska 2018). W niniejszym numerze tę samą perspektywę przyjmuje Agata Lisiak, pisząc o dziewczyńskim oporze w różnych regionach świata. Jest to perspektywa słabego oporu podejmowanego przez słabe zbiorowości, właśnie w proteście, niezgodzie i uporze budujące swoją solidarność.

Wybór tematyki słabości jako wiodącego zagadnienia wydawać się może odosobniony w szerszej panoramie polskiego piśmiennictwa. O ile w krajach Zachodnich faktycznie sporo uwagi poświęca się tej problematyce, u nas nadal znajduje się ona na nieco marginesie. Oczywiście nie musimy wszystkiego kopiować na modłę zachodnią i ostatecznie chyba przecież nie kopiujemy, niemniej trend rewidowania heroicznej, męskiej polityki jest według mnie nieco bardziej obecny poza Polską... ale możemy to sprawdzić. W obszarze 
filozofii i teorii kultury oraz sztuki niemało mówi się na ten temat. Wspomniałam już o interpretacji Vattimo zaproponowanej przez Andrzeja Zawadzkiego. Do myśli Vattimo nawiązuje też Katarzyna Kasia, tłumaczka autobiografii tego autora oraz specjalistka w zakresie między innymi włoskiej estetyki (2007; 2010; 2019). W styczniu 2017 roku na Uniwersytecie Warszawskim odbyła się debata „Od słabej myśli do słabego czynu”, którą miałam przyjemność prowadzić. Wzięły w niej udział między innymi autorki zawartych w numerze tekstów - Katarzyna Szafranowska (Artes Liberales UW) i Justyna Jaworska (IKP UW). Nasz „call for papers” odziedziczył po tym panelu swój tytuł, niemniej proponujemy nieco inny tytuł numeru ze względu na wyłonienie się słabego oporu jako najbardziej doreprezentowanego tu tematu. Popularność eseju Havla Siła beasilnych jest w Polsce nadal spora, co daje się zauważyć głównie w odniesieniach publicystycznych, choć posługuja się nią również filozofowie, jak choćby Szymon Wróbel w wywiadzie zamieszczonym w czasopiśmie Odra z kwietnia 2017 roku czy Andrzej Leder, poświęcający problematyce słabości sporo uwagi w swojej ostatniej książce, Byt kiedyśs postmodernizm (Wróbel 2017; Leder 2019). Książka Natalii Anny Michny Kobiety i kultura. O doświadczeniu w filozofii feministycznej odsłania alternatywy wobec męskiego doświadczania świata i jego teoretycznej analizy w polach epistemologii, estetyki czy teorii krytycznej (2018). Szereg „słabych” wątków wnoszą też prace Joanny Bednarek, zwłaszcza Życie, które mówi. Nowoczesna wspólnota $i$ zwierz̨eta, gdzie perspektywa posthumanistyczna analizowana jest jako możliwość wychodzenia z dominacji, choć niekoniecznie jako koniec przemocy (2017). Zbiorowe opracowanie pod redakcja Elżbiety Korolczuk, Beaty Kowalskiej, Jennifer Ramme oraz Claudii Snochowskiej-Gonzales Bunt kobiet. Czarne Protesty i Strajk Kobiet proponuje między innymi - wymuszoną protestami kobiecymi w Polsce w ostatnich latach - redefinicję kategorii obywatelstwa, w której zaczyna się znajdować miejsce również dla kobiet, nie tylko w ramach częstszego używania tzw. „żeńskich końcówek”, ale również, a może nawet przede wszystkim, w ramach włączania elementów kobiecego doświadczenia i socjalizacji do sfery publicznej (Korolczuk et al. 2019).

Temat strukturalnego przekształcania sfery publicznej przez kobiety i ruchy feministyczne podjęłam w dwóch własnych książkach - antologii Tramwaj zwany uðnaniem. Feminiżm i solidarność po neoliberalizmie oraz Kontrpubliczności ludowe i feministyczne. Wczesna „Solidarnośc”" i Czarne Protesty (2017; 2018). Postulując w nich między innymi widowiskowe wzmocnienie widzialności sprawczego charakteru słabych i bezsilnych - kobiet, osób spoza wielkich metropolii, a także tych wykluczonych klasowo czy kulturowo - spotkałam się oczywiście z zarzutem lansowania „zwyczajności” niejako wbrew wspólnocie kobiet, miejscami niezręcznie owijanym w narrację o rasizmie. To zderzenie prób wspierania procesu wychodzenia feminizmu z ławkowego getta, w jakim zniewolony został on głównie przez prawicową publicystykę, z oczywistym przywilejem niektórych feministek i ich lękami przed 
utratą tej niewielkiej, ale jednak istniejącej hegemonii w zakresie tworzenia ruchu kobiecego czy jego teorii, szczęśliwie ustaje na rzecz refleksyjnego podejmowania takich zagadnień jak obywatelstwo czy kontrpubliczności z jednej strony i dywersyfikacji praktyk oraz stanowisk feministycznych $-\mathrm{z}$ drugiej. Ciekawą pozycja, w której słabość jest bezpośrednio tematyzowana, choć w oczywisty sposób stanowi też ważny temat argumentacji, jest książka Matka Polka na odlegtość. Z doświadczeń migracyjnych robotnic Sylwii Urbańskiej, która nie tylko podjęła się trudu skonstruowania własnej teorii, osadzonej w nurcie „wywiadu refleksyjnego”, ale też prześledziła losy ważnej, choć w Polsce chyba niewystarczająco dobrze zbadanej grupy polskich matek-migrantek (Urbańska 2015).

Wszystkie wymienione tu autorki podejmuja problematykę podmiotowości, sprawczości, kobiecości oraz wskazuja na nie-heroiczne, słabe i prekarne strategie podejmowane przez jednostki i zbiorowości jako alternatywy dla hegemonicznego, męskiego modelu sprawczości, jedynego widzialnego w tradycyjnej filozofii, socjologii i kulturze. Publikacje te dotyczą różnych obszarów, niemniej prześwieca im ta sama idea, zgodnie z która - by odwołać się do znanej polskiej „słabej bohaterki”, Henryki Krzywonos „ten tramwaj dalej nie pojedzie”, a konkretniej: hegemoniczna, heroiczna, zachodnia podmiotowość musi ustapić miejsca wszystkim ,innym”, których dotąd utrzymywała w prekarności (Lorey 2015).

W paradygmacie neoliberalnym produktywność, sukces i separacja jednostki od jej relacji, otoczenia i kontekstu nabrały szczególnego znaczenia. Jesteśmy, jak stwierdza Hito Steyerl, zobowiązane i zobowiązani do „autentycznego bycia” (Heidegger 1994) nie tylko w jednym miejscu i czasie, ale w ich wielości (Steyerl 2015). Musimy być menedżerkami i gwiazdami estrady jednocześnie, musimy przyswajać tajniki pracy zespołowej, pielęgnując zarazem własną niepowtarzalność i wyjątkowość. Szkoły, uniwersytety, fabryki, urzędy, firmy, przedszkola, a nawet artystyczne czy aktywistyczne kolektywy szybko pęcznieja od tych sprzeczności, generując predylekcję do logiki „mierny, ale wierny”, a zarazem celebrując wyjątkowość w jej wszelkich odmianach, ze szczególnym uwzględnieniem pracoholizmu, bulimii, karierowiczostwa oraz zaburzeń psychicznych. Polska w zakresie każdego z tych zjawisk jest $\mathrm{w}$ awangardzie Europy i świata, ale proponowane $\mathrm{w}$ niniejszym numerze rozważania są dalekie od entuzjastycznej aklamacji tych wyborów, nie tylko kontestując i krytykując neoliberalną logikę sukcesu i triumfalistyczną narrację, lecz i wprost opowiadając się po stronie opresjonowanych, marginalizowanych i słabych. W polu sztuki właśnie takim postawom hołdowała feministyczna artystka Mierle Landerman Ukeles, której Manifest sə̧tuki opieki zdecydowaliśmy się przedrukować na potrzeby tego numeru. Analogicznie, choć z większym zacięciem rewizjonistycznym, wybrzmiewa esej Borisa Groysa Staby uniwersalizm, pokazujący nieco mniej znana, a bardzo potrzebną historię dwudziestowiecznych awangard artystycznych jako ruchów budujących wspólnotę poprzez osłabianie heroizmu, praktyk 
analogicznych do Benjaminowskiego „słabego mesjanizmu”. Te dwa teksty otwieraja numer jako rewizja i zaprzeczenie heroicznych modeli sztuki, figury geniusza, artysty czy awangardy uprawianych w sposób typowy dla patriarchalnej hegemonicznej męskości.

Kolejny dział numeru, „Słaby opór, słaby ekran i peryferyjna tożsamość” zawiera dwa teksty. Pierwszy, skupiony na peryferyjności, to dyskusja dziewczyńskich strategii oporu i kontrpubliczności, drugi zaś omawia filmowe strategie reprezentowania peryferyjnego obywatela peryferyjnym obiektywem w dobie odwilży i konsumpcyjnego szału. Agata Lisiak w eseju Poza girl power: driewcżyński opór, kontrpubliczności i prawo do miasta zabiera nas w podróż po frontach i taktykach współczesnych wojen płciowych i kulturowych, zaś Justyna Jaworska w tekście „Klir” i obraz staby w filmie Hair Marka Piwowskiego przybliża nam polskie kino pierwszej dekady lat siedemdziesiątych i szuka strategii dyskutowania pracy porażki i nieudolności w budowaniu już nie heroicznego podmiotu półperyferyjnego.

Kolejna, trzecia część numeru, zatytułowana jest „Słaby mesjanizm wobec końca demokracji” i zawiera esej Katarzyny Szafranowskiej Moc stabości w obliczu katastrofy. Mesjańskie poprawki Waltera Benjamina, Gianniego Vattimo $i$ Harolda Blooma. Autorka omawia tu przede wszystkim porażkę projektu demokratycznego, a widmu faszyzmu zasnuwającemu coraz bardziej niebo Europy i świata przeciwstawia dekonstruktywistyczne i benjaminowskie strategie oporu.

Numer zamyka dział „Odzyskiwanie: środowisko, edukacja i przyszłość”, w którym Magdalena Barbaruk, autorka tekstu Opór naturalny. Amereida jako nieheroiczna wyprawa $i$ uniwersytet bezwarunkowy, oraz Tymon Adamczewski, autor artykułu Weakness, Lameness and Veering. On Practical Dimensions in the Theories of Ecocriticism, podejmuja próbę zmierzenia się $z$ literacko-edukacyjnym (Barbaruk) oraz spekulatywno-teoretycznym (Adamczewski) wymiarem debaty na temat przyrody i środowiska naturalnego, wybierając perspektywy kontrastujące z ideałami linearności, heroizmu i jednoznaczności.

$\mathrm{Na}$ zakończenie chciałabym bardzo serdecznie podziękować Autorkom i Autorowi, Recenzentom i Recenzentkom, Redaktorkom i Redaktorom, szczególnie Mateuszowi Janikowi oraz Mikołajowi Ratajczakowi za bardzo owocną i często niezwykle intensywną współpracę. Jestem też bardzo wdzięczna osobom dokonującym składu, korekty, promującym ten i inne numery pisma on-line, a także Autorowi okładki, Ygrekowskiemu. Chciałabym również zadedykować ten numer Praktyki Teoretycznej wszystkim matkom, zwłaszcza samodzielnym i pracującym, a już szczególnie matkom pracującym w akademii, z których kilka napisało dla nas teksty. Myślę, że figura słabego oporu jest w ich życiu szczególnie ważna, a siła, z jaką uporczywie i pomimo licznych przeciwności realizują swoja pracę badawcza, dydaktyczną i coraz częściej również administracyjną, zdecydowanie zasługuje na uwidocznienie, nie tylko od święta, ale i na co dzień. 


\section{Wykaz literatury}

Agamben, Giorgio. 2008. Homo Sacer. Suwerenna władz̨a i nagie sycie. Tłum. Sławomir Królak. Warszawa: Prószyński i S-ka.

Ahmed, Sara. 2014. Willful Subjects. Durham and London: Duke University Press.

Butler, Judith. 2010. Walczqce słowa. Tłum. Adam Ostolski. Warszawa: Wydawnictwo Krytyki Politycznej.

Butler, Judith i Gayatri Ch. Spivak. 2007. Who Sings the Nation State? Calcutta, New York and Oxford: Seagull Books.

Diderot, Denis. 1958. Paradoks o aktorze. Tłum. Jan Kott. Warszawa: Wydawnictwo Czytelnik. Federici, Silvia. 2004. Caliban and the Witch. New York: Autonomedia.

Foucault, Michel. 1984. "Des Espaces Autres." Architecture, Mouvement, Continuité 5: 46-49.

Habermas, Jürgen. 2008. Strukturalne præeobrażenia sfery publicznej. Tłum. Małgorzata Łukasiewicz, Wanda Lipnik. Warszawa: Wydawnictwo Naukowe PWN.

Halberstam, Jack (Judith). 2011. The Queer Art of Failure. Durham: Duke University Press. Havel, Vaclav. 2011. Siła bezsilnych i inne eseje. Tłum. Andrzej Jagodziński. Warszawa: Agora. Hardt, Michael i Antonio Negri. 2017. The Assembly. New York: Oxford University Press. Hegel, Georg Wilhelm Friedrich. 1963. Fenomenologia ducha. Tłum. Adam Landman. Warszawa: PWN.

Heidegger, Martin. 1994. Bycie i czas. Tłum. Bogdan Baran. Warszawa: Wydawnictwo Naukowe PWN.

Honig, Bonnie. 2013. Antigone, Interrupted. Cambridge: Cambridge University Press. hooks, bell. 2013. Teoria feministyczna. Od marginesu do centrum. Tłum. Ewa Majewska. Warszawa: Wydawnictwo Krytyki Politycznej.

Jaworska, Justyna. 2019. „Piękne widoki, panowie, skad macie”. O kinie polskiego socjokonsumpcjoniżmu. Kraków: Universitas.

Kluge, Aleksander i Oskar Negt. 2016. Public Sphere and Experience. Tłum. Peret Labanyi i in. London: Verso.

Korolczuk, Elżbieta. 2019. Matki i córki we wspótczesnej Polsce. Kraków: Universitas.

Korolczuk, Elżbieta, Beata Kowalska, Jennifer Ramme i Claudia Snochowska-Gonzales (red.). 2019. Bunt kobiet - Czarne Protesty i Strajki Kobiet. Gdańsk: ECS.

Leder, Andrzej. 2019. Byt kiedyśs postmodernizm... Sześć esejów o schy tku XX stulecia. Warszawa: Wydawnictwo IFiS PAN.

Majewska, Ewa. 2018. Kontrpubliczności ludowe i feministyczne. W cæuesna „Solidarnośç” i Czarne Protesty. Warszawa: Instytut Wydawniczy Książka i Prasa.

Majewska, Ewa, Elżbieta Korolczuk, Julia Kubisa i Katarzyna Rakowska. 2019. „From the Women's Strike to the Feminist International: In Struggle We Unite - Voices from Poland." Viewpoint Magazine. https://www.viewpointmag.com/2019/06/18/from-thewomens-strike-to-the-feminist-international-in-struggle-we-unite-voices-from-poland/ (dostęp 29.06.2019).

Marzec, Wiktor. 2015. Rebelia i reakcja. Rewolucja 1905 roku i plebejskie doświadczenie polityczne. Kraków: Universitas.

Michna, Natalia Anna. 2018. Kobiety i kultura. O doświadczeniu w filozofii feministycz̨nej. Kraków: Wydawnictwo Uniwersytetu Jagiellońskiego.

Ochocki, Aleksander. 2003. Trzy opery i podmiotowość komiczna. Warszawa: Fundacja Aletheia.

Peters, Sybille. 2016. „Wprowadzenie.” W Prawda jest konkretna. Red. Florian Malzacher. Warszawa: Fundacja Bęc Zmiana.

Scott, James. 1985. Weapons of the Weak. New Heavens and London: Yale University Press. 
Spivak, Gayatri. 2011. „Czy podporządkowani inni mogą przemówić?” Tłum. Ewa Majewska. Krytyka Polityczna 25-26: 196-239.

Steyerl, Hito. 2015. The Wretched of the Screen. Berlin: e-flux and Sternberg Press.

Urbańska, Sylwia. 2015. Matka Polka na odlegtość. Z doświadczeń migracyjnych robotnic 1989- 2010. Toruń: Fundacja na Rzecz Nauki Polskiej.

Vattimo, Gianni, Pier Aldo Rovatti i Peter Carraveta (red.). 2012. Weak Thought. New York: SUNY Press.

Wróbel, Szymon i Jola Workowska. 2017. „Siła niemocy - wywiad.” Odra 4.

Zawadzki, Andrzej. 2003. „Noica, Vattimo: »myśl słaba« i jej konsekwencje”. Teksty Drugie 6: 167-178. 
Ewa Majewska - filozofka feministyczna i aktywistka. Wykładała na Gender Studies i Wydziale Artes Liberales UW, była stypendystką ICI Berlin oraz IWM w Wiedniu, prowadziła badania w UC Berkeley w USA. Opublikowała książki: Kontrpublicz̨ności ludowe $i$ feministyczne (2018), Tramwaj zwany uznaniem. Feminizm i solidarność po neoliberalizmie (2017), Sztuka jako pozór? Cenzura i inne formy upolityczniania kultury (2013), Feminizm jako filozofia społeczna. Szkice z teorii rodziny (2009); współredagowała tomy: Zniewolony umyst II. Neoliberalizm i jego krytycy oraz Futuryzm miast przemystowych. Jest autorka artykułów i esejów m. in w: e-flux, Signs, Third Text, Pržgladzie Filozoficznym, Etyce, Kulturze Wspótczesnej, Prz̧ekroju, Praktyce Teoretycznej.

\section{DANE ADRESOWE:}

Gender Studies UW

ul. Nowy Świat 69

00-727 Warszawa

EMAIL: ewamajewska@o2.pl

CYTOWANIE: Majewska, Ewa. 2019. „Słaby opór. Obraz, wspólnota i utopia poza paradygmatem heroicznym". Praktyka Teoretyczna 2(32): 7-20

DOI: $10.14746 / \operatorname{prt} .2019 .2 .0$

\section{AUTHOR: Ewa Majewska}

TITLE: Weak Resistance: Image, Community and Utopia Beyond the Heroic Paradigm

ABSTRACT: This article is the Preface for Praktyka Teoretyczna's issue on the problem of weak resistance. It discusses the main theoretical inspirations behind the turn towards the ordinary and everyday and the resignation from heroic models of subjectivity. This text also introduces the articles published in this issue.

KEYWORDS: weak resistance, counterpublics, weak messianism, subject, the common. 